\title{
Analysis of Railway Information Processing Platform
}

\author{
Dechao Liu ${ }^{1, a}$, Leiqiang $\mathrm{He}^{2, \mathrm{~b}}$ and Qin $\mathrm{Niu}^{2, \mathrm{c}}$ \\ ${ }^{1}$ School of Beijing Jiaotong University, Beijing 100044, China; \\ ${ }^{2} \mathrm{~S}$ China Academy of Railway Sciences, Beijing 100081, China. \\ aliudechaoldc@163.com, b13466628198@126.com, niuqin07@ccc.com
}

Keywords: Railway risk management, Risk evaluation, Information processing platform.

\begin{abstract}
The existing safety production management system in the railway department is despised in the prior research, and pays attention to the post processing. The leaders at all levels and risk managers have a comprehensive grasp of the risk management of railway demand, according to the general principles of modern risk management, put forward the corresponding function requirements of railway risk management information processing platform. Relying on Railway Bureau integrated IT network, the establishment of security risk management information service platform, will provide a new technical support for railway safety risk management system.
\end{abstract}

\section{Introduction}

With the rapid development of large area of railway and high-speed railway construction, China's railway in the process of high-speed, heavy load, high density transport development in the process of ${ }^{[1]}$, the risk and risk factors are also gradually increasing and complicated. The existing safety production management system in the railway department is relatively backward, and lack of systematic scientific methods in the process of leading prevention and management ${ }^{[2]}$.

This paper uses the theory and method of network information technology security risk management, the risk management method suitable for railway, clear functional requirements of railway risk management information management platform, the establishment of railway safety risk information disposal platform of network application, providing technical support for the global push for security risk management system.

\section{Demand analysis of railway information processing platform}

\section{User Demand}

(1) Leaders at all levels of the railway

Fully grasp the railway risk management, including the main risk, risk response, risk control.

(2) Risk management personnel of Railway General Company

Responsible for the railway company level risk management, including risk assessment information entry, audit, information classification and risk audit, risk information database maintenance, risk control instructions issued by the audit bureau, railway risk control rules.

(3) Risk management personnel of Railway Administration

The railway bureau responsible for the risk management, including risk assessment information entry, audit, information entry, audit risk classification, risk information database maintenance, risk assessment of the results of the check, the weights of the evaluation indexes of risk adjustment and risk control rules issued under section specific risk control measures of the audit.

(4) Personnel risk management of railway station

The railway bureau responsible for the risk management, including risk assessment information input, information classification and risk input, risk evaluation results of view, risk control measures issued.

(5) Other users 
Can look at the level of the risk information database, the main risk of the main risk and other basic information.

(6) System management personnel

User and rights management, platform operation parameter configuration, basic data maintenance, etc..

\section{Functional Requirement}

The function requirements of railway risk management information processing platform mainly include the following aspects.

(1) The railway risk assessment requirements. Risk assessment is the basis function of railway risk information disposal platform, it is the main task of the railway departments at all levels based on the theory and method of risk analysis, find out the cause accidents, leading to unsafe behavior, the adverse consequences of the unsafe condition of things, bad work processes and poor working environment etc..

(2) The risk of railway risk rating functional requirements. Based on the risk assessment on the estimation of risk occurrence probability and severity, determine the level of risk. The management department can determine the priority sequence of risk control according to the risk level, and put the limited security resources into the control of the high risk events, and improve the safety of the railway.

(3) The functional requirements of railway risk assessment. The specific functional requirements for safety, risk of Railway Bureau for each station were evaluated and ranked, found recently prominent information security risk, improve the level of safety management, to provide reference for prevention of accidents of railway management department.

(4) The risk control function demand of railway risk. Based on the risk assessment results, the management personnel of the railway department analyze the risk factors of the current period, and make the control measures and control objectives.

(5) The risk of railway risk supervision and inspection requirements. Through inspection, found that the units did not reach the risk control objectives of the risk factors, so as to carry out rectification and adjustment, to achieve the goal of risk control to provide protection.

The above several links, the division of labor is clear, the connection is orderly, has formed the railway risk management organic whole.

\section{Platform overall design scheme}

\section{Overall framework of the system}

The related computer servers and software deployment in the railway company and the Railway Bureau, the establishment of security risk management information service platform, realize the risk information management, risk control and risk management of daily inspection based on Railway Bureau comprehensive evaluation; IT network (the original TMIS production is down to the network), the main workshop stations, using network connectivity; B/S network application mode, railway company, railway station, station risk information management.

\section{System logic structure}

Railway safety risk information processing platform is divided into system application layer, business logic layer and data layer from the system logic structure. 


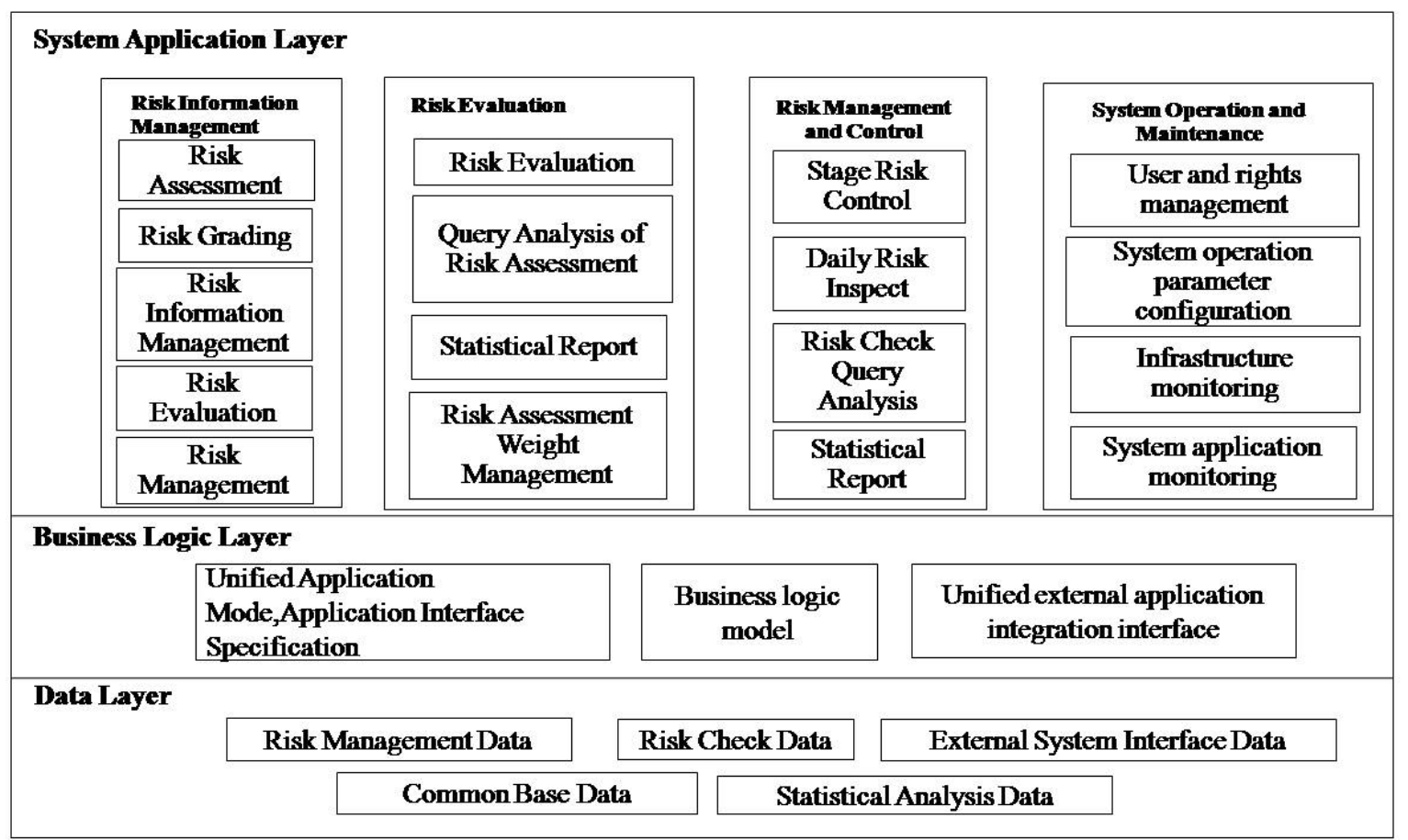

Fig. 1 logical structure of the platform

The application layer includes risk information management, risk evaluation, risk control management, mainly to provide application services for information management for leaders to query, business department; business logic layer includes a unified application platform model, interface specification design, logical model and external application integration interface; data layer lies in the establishment of centralized data storage that is conducive to efficient access.

\section{System function module design}

The main functional requirements on the basis of Railway Corporation, including railway risk assessment standards (levels of risk control table), risk classification standard, step by step review and classification of risk identification, identify all kinds of risk level, put forward and tracking the implementation of major hazard control measures and emergency treatment plan: to construct and realize electronic security unit risk assessment; risk management according to the demand, establish the corresponding statistical analysis report automatic generation function.

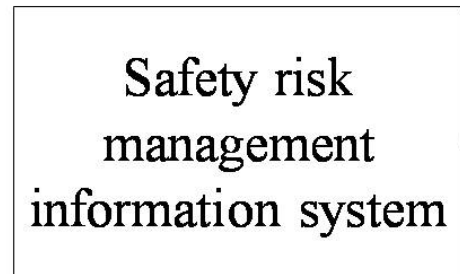

\begin{tabular}{|c|}
\hline Risk Assessment and Management \\
\hline Risk Grading Management \\
\hline Risk Information Management \\
\hline Risk Evaluate Management \\
\hline Risk Control Management \\
\hline Statistical Report \\
\hline Statistical Report \\
\hline
\end{tabular}

Fig. 2 Schematic diagram of system function structure 
Security risk assessment management, according to the collection and approval process and other requirements, the establishment of railway company, railway station, station three (high, middle and low) risk source recognition database, and updated regularly. Specific function list is as follows:

Table 1 risk assessment module

\begin{tabular}{|c|c|c|}
\hline Function Point & Function description & Access control \\
\hline Risk event entry & $\begin{array}{l}\text { Enter the newly identified risk } \\
\text { event information }\end{array}$ & All user \\
\hline $\begin{array}{c}\text { Risk event modification and } \\
\text { deletion }\end{array}$ & $\begin{array}{l}\text { Can be modified before } \\
\text { reporting, delete }\end{array}$ & All user \\
\hline Risk event query & & All user \\
\hline Risk event reporting & $\begin{array}{l}\text { The station reported to be } \\
\text { reported to the audit bureau of } \\
\text { railway risk information; }\end{array}$ & $\begin{array}{c}\text { The user, the user station } \\
\text { Railway Bureau }\end{array}$ \\
\hline Risk event audit & $\begin{array}{l}\text { Railway Bureau reported total } \\
\text { audit risk information } \\
\text { Audit risk event level, } \\
\text { classification, main control } \\
\text { measures are correct, can be } \\
\text { called back. }\end{array}$ & $\begin{array}{l}\text { The railway company, railway } \\
\text { stations, user user user }\end{array}$ \\
\hline
\end{tabular}

Security risk classification management, to have identified the risk information, in accordance with the existing risk classification model, combined with experience, the classification of risk information classification management. Specific function list is as follows:

Table 2 risk classification management module

\begin{tabular}{|c|c|c|}
\hline Function Point & Function description & Access control \\
\hline $\begin{array}{l}\text { Security risk grading results } \\
\text { release }\end{array}$ & Rating for risk information & $\begin{array}{l}\text { The railway company, railway } \\
\text { stations, user user user }\end{array}$ \\
\hline Risk event modification & $\begin{array}{l}\text { According to the actual risk } \\
\text { management, to re adjust the } \\
\text { level of risk events }\end{array}$ & $\begin{array}{c}\text { Railway Corporation user, } \\
\text { Railway Bureau user }\end{array}$ \\
\hline
\end{tabular}

Security risk assessment management, the main function is the security risk evaluation of each business section of security risk evaluation model, based on the needs of management, can adjust the weight of index.

Table 3 risk classification management module

\begin{tabular}{ccc}
\hline Function Point & Function description & Access control \\
\hline $\begin{array}{c}\text { Security risk grading results } \\
\text { release }\end{array}$ & $\begin{array}{c}\text { Make evaluation for the risk } \\
\text { state of each business section } \\
\text { According to the management } \\
\text { need, the weight of risk } \\
\text { adjustment }\end{array}$ & All user \\
evaluation index is adjusted. & Railway Bureau user \\
Analysis of safety risk & Compare the results of this \\
assessment & month and last month, analyze \\
& the tendency of risk & All user \\
\hline
\end{tabular}

\section{Interface design of information platform}

The information platform to collect relevant data from external systems, such as mobile phone accident from the existing railway safety supervision and management information system in the analysis of the survey data, monitoring data, provide data support for the risk assessment of the information platform, so the data integration mode, to achieve access to relevant data from external system and comprehensive use. 
Publish the relevant data interface in the application server Web Service Bureau existing railway safety supervision and management information system, railway safety risk information disposal platform through the railway administration office network call related services to obtain basic data and business data.

Transmission of information include: accident information, equipment monitoring information, security inspection information, basic information, other information.

\section{Summary}

Based on the existing railway safety production management system were analyzed, based on determining the user needs and functional requirements, the establishment of railway safety risk management information processing platform, provides a new technical means for railway safety risk management system, has the practical significance, the risk evaluation system for a railway administration are applicable, still need concrete analysis.

\section{References}

[1] Song Cao, Theory and method of railway traffic safety early warning [D]. Beijing: China Academy of Railway Science, 2011

[2] Zhongjing Wu, Research and implementation of [D]. Beijing special railway safety evaluation and safety warning system: Beijing Jiaotong University, 2010 